International Labor and Working Class History

Number 17, Spring 1980, pp. 46-50

\title{
STUDY GROUP ON INTERNATIONAL LABOR AND WORKING CLASS HISTORY ANNUAL MEETING
}

The Study Group on International Labor and Working Class History sponsored a panel discussion and business meeting on December 28, 1979, at the meeting of the American Historical Association in New York City. The discussion focussed upoil the restructuring of capital after 1918 and its effect upon the workplace, the working class community, and the state. The first speaker, Alex Keyssar, discussed the restructuring of labor markets in the United States. Tim Mason followed with comments on the growing role of the state as an employer. Molly Nolan drew upon her studies of German social democracy before, during, and after World War II to describe the role of socialist parties in the organization of the working class. Victoria deGrazia examined the functions of organized leisure in the remaking of the Italian working class under the fascist regime. Finally, Frederick Cooper, drawing on his work in East Africa, talked about the organization of labor and working class culture in underdeveloped societies with a relatively rationalized industrial system. About 200 people attended the session, and the discussion following the five talks was lively and provocative.

A much smaller number, about thirty-five, remained for the business meeting. Both the Continuation Committee and the edirorial staff of ILWCH expressed the need for a revitalized Study Group and for a closer working relationship between the Study Group and ILWCH. Study Group members were encouraged to expand the group in their local areas. It was decided to appoint a Coordinator of the Study Group to organize the session at next year's AHA meeting. The Coordinator was given the responsibility as well to appoint five regional representatives to coordinate regular regional reports and additional input of the Study Group in ILWCH. Dale Newman, of the University of Pittsburgh, was subsequently chosen as the interim Coordinator for a term of one year. The regular coordinator, who will serve for a term of two years, will be elected at the next AHA meeting.

The next issue of ILWCH will include the names of the five new regional representatives, as well as the reports submitted by each. The meeting place, time and possible agenda items of the next Study Group meeting at the AHA conference will also be announced. Since a new Coordinator of the Study Group will be elected at this meeting, all members are urged to attend. In the meantime, anyone with suggestions concerning the Study Group and its input into ILWCH should write Dale Newman, Forest Road, Bradfordwoods, PA 15015.

\section{Arlyn Miller}

Yale University 